\title{
Morphological characterization of colorectal pits using autofluorescence microscopy images
}

\author{
Luciana Ariadna ERBES ${ }^{1,2}$, Ángel Alberto ZEITOUNE ${ }^{1,2}$, Humberto Maximiliano TORRES ${ }^{3}$, \\ Víctor Hugo CASCO ${ }^{1,2}$ and Javier ADUR ${ }^{1,2}$
}

Received 19/3/2019 Accepted 10/6/2019

\begin{abstract}
Background - Colorectal cancer is one of the most prevalent pathologies. Its prognosis is linked to the early detection and treatment. Currently diagnosis is performed by histological analysis from polyp biopsies, followed by morphological classification. Kudo's pit pattern classification is frequently used for the differentiation of neoplastic colorectal lesions using hematoxylin-eosin stained samples. Few articles have reported this classification with image software processing, using exogenous markers over the samples. The processing of autofluorescence images is an alternative that could allow the characterization of the pits from the crypts of Lieberkühn, bypassing staining techniques. Objective - Processing and analysis of widefield autofluorescence microscopy images obtained by fresh colon tissue samples from a murine model of colorectal cancer in order to quantify and characterize the pits morphology by measuring morphology parameters and shape descriptors. Methods - Adult male BALB/cCmedc strain mice $(\mathrm{n}=27)$, ranging from 20 to $30 \mathrm{~g}$, were randomly assigned to four and five groups of treated and control animals. Colon samples were collected at day zero and at fourth, eighth, sixteenth and twentieth weeks after treatmentwith azoxymethane. Two-dimensional (2D) segmentation, quantification and morphological characterization of pits by image processing applied using macro programming from FIJI. Results - Type I is the pit morphology prevailing between 53 and $81 \%$ in control group weeks. III-L and III-S types were detected in reduced percentages. Between the 33 and $56 \%$ of type I was stated as the prevailing morphology for the 4th, 8 th and 20th weeks of treated groups, followed by III-L type. For the 16 th week, the $39 \%$ of the pits was characterized as III-L type, followed by type I. Further, pattern types as IV, III-S and II were also found mainly in that order for almost all of the treated weeks. Conclusion - These preliminaries outcomes could be considered an advance in two-dimensional pit characterization as the whole image processing, comparing to the conventional procedure, takes a few seconds to quantify and characterize non-pathological colon pits as well as to estimate early pathological stages of colorectal cancer.
\end{abstract}

HEADINGS - Colorectal neoplasms. Colonic polyps, diagnosis. Aberrant crypt foci. Fluorescence microscopy. Inbred Balb/c mice.

\section{INTRODUCTION}

Colorectal cancer (CRC) is one of the diseases with the highest incidence and mortality worldwide ${ }^{(1)}$ whose prognosis strictly depends on early detection and therapy of premalignant and malignant lesions ${ }^{(2)}$. It commonly arises from adenomatous polyps, which may progress into invasive adenocarcinomas over time ${ }^{(3,4)}$. Currently diagnosis are performed by histological analysis from polyp biopsies ${ }^{(3)}$.

Neoplastic and adenomatous polyps discrimination by colonoscopy is important since the removal or biopsy of hyperplastic polyps implies loss of time and resources, and might increase the incidence of bleeding and perforation ${ }^{(5,6)}$. Despite screening for polyps via conventional white light colonoscopy had reduced the overall mortality ${ }^{(4)}$, it is inadequate for real-time characterization. For details, mucosal surface pattern and vascular architecture can be visualized in vivo by magnifying endoscopy ${ }^{(2)}$.

Kudo et al. ${ }^{(7)}$ established the Kudo's pit pattern classification having analysed the surface mucosal pits using an in vivo magnifying endoscope and an in vitro stereomicroscope, and classified the lumen shape of the crypts. This is one of the morphological classifications proposed that has been proven as a highly accurate diagnostic criterion, frequently used for non-neoplastic and neoplastic colorectal lesions differentiation using samples stained with hematoxylin-eosin (H\&E), as in the classic anatomopathological diagnosis ${ }^{(2,7,8)}$. FIGURE 1 displays the pit pattern representations modified from Kiesslich et al ${ }^{(8)}$ and Liedlgruber ${ }^{(9)}$. That pit pattern is classified based on the crypt pits, its underlying structure and the glands histology ${ }^{(7)}$ : circular pit (Type I); star-shape or papillary pit (Type II); small circular pit, smaller than Type I (Type III-S); large circular or tubular pit, bigger than Type I (Type III-L); branched pit (Type IV); and structureless (Type V). Types I and II are considered normal tissues or with benign changes $(\mathrm{BC})$, hyperplasia and inflammatory polyps, whereas types III to V represent neoplastic and malignant changes $(\mathrm{NC})^{(2)}$. Thus, Kudo's classification obtain clinical relevance owing to the importance in determining if the lesion must or must not be removed ${ }^{(10)}$. Further, variations in shape descriptors has shown to differentiate adenomas from other lesions or between pit patterns, evidencing the significance of morphological analysis ${ }^{(11,12)}$. 


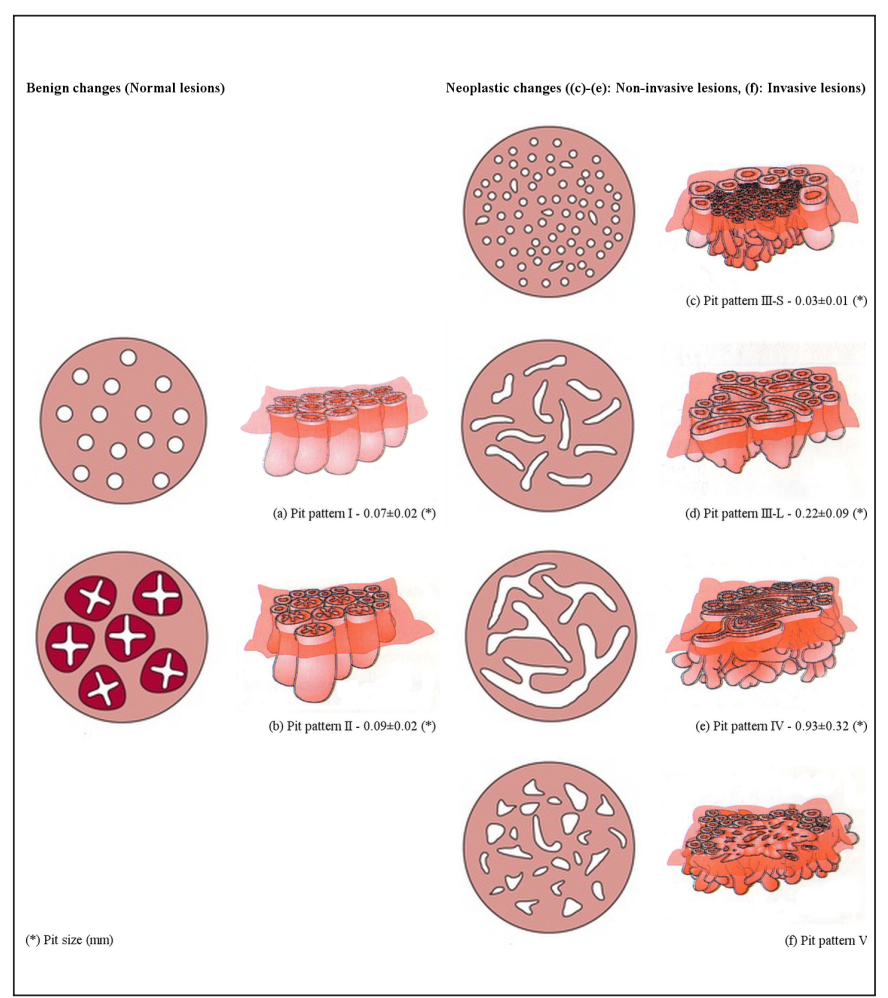

FIGURE 1. Schematic representation of the crypt pattern. Modified from ${ }^{(8,9)}$.

Analyses based on Kudo's classification have been reported using images mainly from magnifying chromoendoscopy $(7,10,12-17)$ or narrow band imaging (NBI) endoscopy ${ }^{(18-24)}$ and optical projection tomography (OPT) ${ }^{(25)}$. Most of them are performed by experienced endoscopists while a few used image software processing $\operatorname{methods}^{(4,12)}$.

Autofluorescence images are an alternative to avoid the use of exogenous markers or staining techniques, since this intrinsic property of cells generated by compounds or organelles could generate tissue differences based on their composition and distribution in the colorectal wall. To our knowledge, a couple of articles have reported the use of autofluorescence to characterize colorectal polyps in CRC screening or to detect neoplasia in patients with ulcerative colitis ${ }^{(21,26)}$.

The proposed method aimed to characterize the pits morphology by quantifying morphological parameters through the processing and analysis of autofluorescence images obtained by fresh colon tissue samples from a murine model of CRC.

\section{METHODS}

\section{CRC murine model}

Adult male $\mathrm{BALB} / \mathrm{cCmedc}$ strain mice $(\mathrm{n}=27)$, ranging from 20 to $30 \mathrm{~g}$, were randomly assigned to four and five groups of treated and control animals. The first were intraperitoneally injected with $10 \mathrm{mg} / \mathrm{kg}$ azoxymethane (AOM; Santa Cruz) at day zero and one week later were treated with Dextran Sodium Sulphate (DSS; MP Biomedicals, Solon, OH, USA) given in the drinking water for seven days, following the Tanaka ${ }^{(18)}$ procedure. Control group mice were saline injected (day zero), and drinking water without DSS was provided.
Colon samples were collected at day zero and at fourth, eighth, sixteenth and twentieth weeks after treatment. Distal colon segments were extracted, longitudinally sectioned, mounted on slides with the luminal surface placed upwards, permanently wetted with saline and immediately observed by fluorescence microscopy. The use of laboratory animals followed the ethical code of International Organization of Medical Sciences for animal's experimentation.

\section{Images acquisition}

Three-dimensional (3D) images were obtained by optical sectioning using an Olympus BX50 microscope (Objective lens: UPlanApo 20X, AN 0,7) and a mercury UV lamp for epifluorescence microscopy (Filter: U-MSWG [BP 480-550, DM 570, BA 590]). Images were recorded with a monochromatic, refrigerated Apogee CCD camera (Andor, Belfast, UK), with 14 bits of resolution and $9 \mu \mathrm{m}^{2}$ of pixel size. They were stored in 8 bit tiff files and consists of 40 optical sections ( $512 \times 512$ pixels) with $0.5 \mu \mathrm{m}$ steps.

\section{Pits pattern characterization methodology}

3D images were photobleaching corrected, through a macro developed in previous works, and digital deconvolved by Richardson-Lucy algorithm from DeconvolutionLab plugin ${ }^{(27,28)}$. A pit segmentation, quantification and characterization method, developed by macro programming from FIJI ${ }^{(29)}$, is applied on the first slice of each image as it belongs to outermost side of the superficial mucosa. It consists of several steps where tools and plugins ${ }^{(30,31)}$ are used by setting the required parameters.

The first slice is extracted from the 3D image. Texture features, such as homogeneity and variance, are acquired to differentiate images and apply alternative steps when necessary. A noise circular pattern is reduced by a median filter and the autofluorescence dotting usually found at the intestinal mucosa surface, is smoothed applying a Gaussian filter. The pits morphology is accentuated by sharpening and enhancing the edges and then, dilation steps are applied to delimitate more the areas with intensities related to pits. The image is inverted and regions whose intensity values are above a threshold are found and the elements placed at the boundaries are removed. Pixel values higher than 0 are set to 255 and a new inversion is made to extract the structures representing pits, specifying a size range of 600 to infinity pixels ${ }^{2}$. The scale is set up and measures about parameters and shape descriptors (area, centroid, perimeter, circularity, aspect ratio, roundness, solidity, elongation, sphericity, Feret's diameter) are acquired over the segmented objects. Then, a characterization is performed by selecting quantification files obtained from the former step. A pit pattern type label from I to IV is assigned to each pit, based on the analysis of the combination of its elongation, sphericity and solidity values. The total number of pits is calculated as well as the percentages found for each pit pattern type. Furthermore, the whole amount of pits is characterized as BC or NC based on the percentage of the prevailing pit pattern type and perimeter averages data published in Kiesslich et al. ${ }^{(8)}$.

Finally, as images had different features owing to treatment, time and animal peculiarities, alternative parameters or steps were applied mainly depending on the homogeneity values, such as the threshold setting to find intensity values above it, a circularity filter addition when extracting the structures and/or the sequentially duplication of the smoothed and enhancing steps. Representative outputs are exemplified in FIGURE 2. 


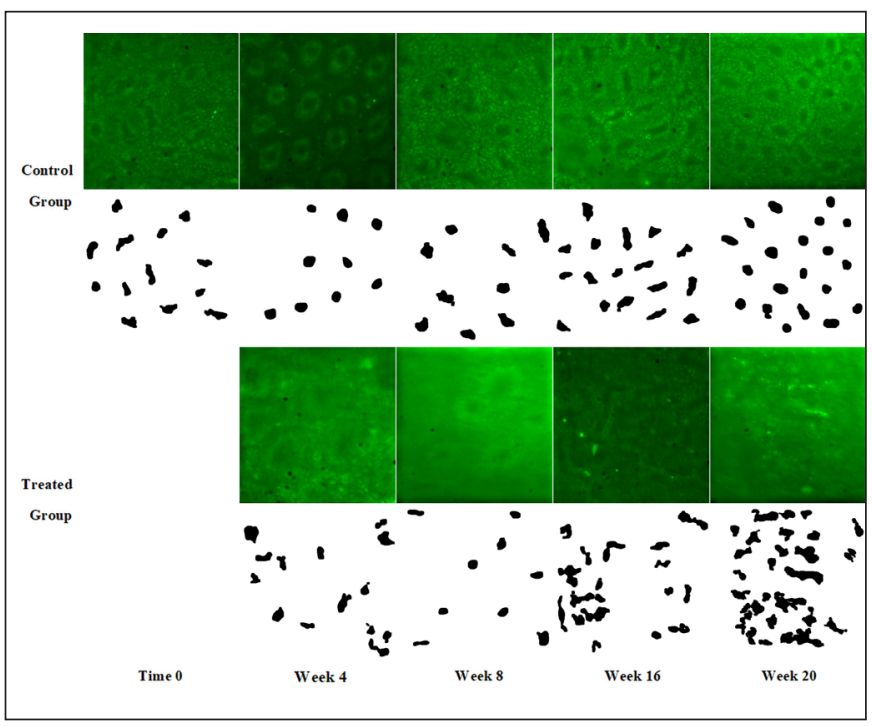

FIGURE 2. Representative examples of each control and experimental induced CRC. Original pseudo-colored images and post-segmentation representations.

\section{Statistics}

For control groups, six, three, three, four and six images were used at time zero and 4th, 8th, 16th and 20th weeks, while three, one, three and four images were used for treated weeks.

A sensitivity analysis evaluated the segmentation accuracy, dividing the true positives by the sum of the true positives and false negatives. The number of pits properly segmented and not segmented, from all samples from each week, were defined as true positive and false negative. A positive predictive value (PPV) tested the probability of true pits segmentation.

Continuous variables are summarized as median and range.

A non-parametric factorial ANOVA was carried out by using ARTool package ${ }^{(32)}$ to determine differences in mean perimeter between 4 th, 8 th, 16 th and 20 th weeks for each treatment type.
Non-parametric Mann-Whitney tests were applied when results were significant, followed by a $P$-value Holm correction.

$P$-values $<0.05$ were considered statistically significant. The analyses were conducted in RStudio ${ }^{(33)}$.

\section{RESULTS}

\section{Pits characterization}

The segmentation stage was validated through sensitivity and PPV analysis. The $76 \%$ of the total segmented pits, discarding the 16th and 20th treated weeks, were properly segmented. Those weeks were not included in the analyses owing to some pits seem to be merged due to the disease progression. In detail, the sensitivity values stated for the time zero, 4th, 8th, 16th and 20th weeks of the control groups were $75 \%, 46 \%, 79 \%, 84 \%$ and $76 \%$ while 0.83 , $0.81,0.79,0.83$ and 0.73 were their respective PPV. The 4 th and 8 th weeks from treated groups obtained $91 \%$ and $80 \%$ sensitivity values as well as 0.64 and 0.89 PPV. FIGURE 2 represents the original pseudo-colored image and the respective segmentation for representative cases.

Subsequent quantification outcomes are displayed in TABLE 1. Control group pits exhibited perimeters that ranges between 0.04 and $0.12 \mathrm{~mm}$ whereas the ones from the treated group shown a wider range where the largest perimeter is close to $1 \mathrm{~mm}$. The same behavior is observed in almost all of the areas from the treated group weeks regarding de control weeks. Both parameters exhibited decreasing values in the 8 th treated week and despite its pit pattern was characterized as $\mathrm{BC}$, that reduction might evidence a transition between pathology stages, tending to adopt a neoplastic pattern. The values quantified for treated animals of 16th and 20th weeks exhibited an increment which could be a consequence of the quantification of branched pits (Type IV) or from the possible coalescent pits instead of individual structures.

The interaction between time and treatment factors (FIGURE 3) was determined by a statistically significant $P$-value $(P$-value $=1.0252 \mathrm{e}-05)$. By cross-factor pairwise comparisons, statistically differences in mean perimeters were found between the

TABLE 1. Pits morphology quantification and characterization using autofluorescence images from control and treated groups.

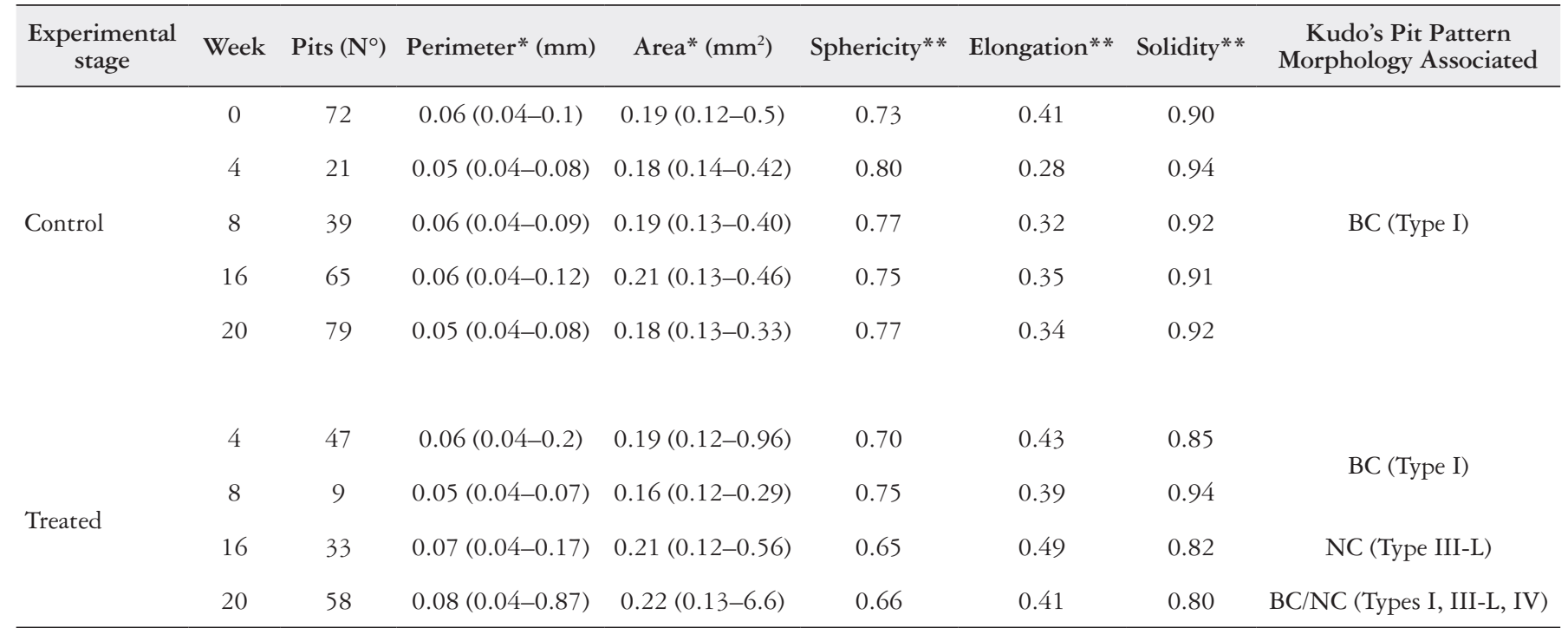

BC: benign changes. NC: neoplastic changes. * Median and range. ** Mean. 


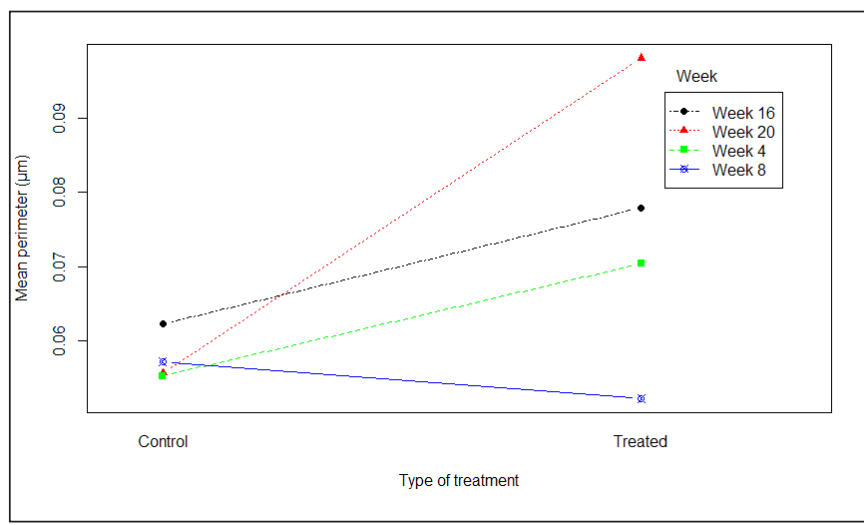

FIGURE 3. Two-way combinations of factor interaction plot.

20 th week from control and the 4 th $(P$-value $<0.05), 16$ th and 20 th $(P$-value $<0.01)$ weeks from treated groups, the 4 th control week and the 16th and 20th treated weeks $(P$-value $<0.05)$ as well as the 8 th control week and the same treated weeks $(P$-value $<0.01)$ and lastly, the 16th and 20th weeks from control and treated groups $(P$-value $<0.05)$.

The pit pattern characterization considering sphericity, elongation and solidity parameters showed that the majority of the control group pits had averaged sphericity and elongation values relating to roundish morphologies while averaged solidity parameter stated that the edges of the pits were not rough, assigning Type I as the prevailing type between $53 \%$ and $81 \%$ for each week. Moreover, type III-L was detected from 10\% to 33\% (except for the 8th week where this type was not found) and III-S from $3 \%$ and $11 \%$. More pattern types were characterized in the treated groups, including II and IV types. In particular, type I was also stated in 51, 56 and $33 \%$ as the prevailing morphology for the 4 th, 8 th and 20 th weeks followed by $21 \%$ to $25 \%$ of III-L type, while type III-L was the most representative pattern for the 16th week in the $39 \%$ of the pits followed by $24 \%$ of type I. For the 8 th week, III-S exhibited the same percentage as III-L. Type IV was set in the third place for the 4th, 16 th and 20 th weeks, ranging from $14 \%$ to $18 \%$. Finally, type III-S was found from $2 \%$ to $6 \%$ in 4 th, 16 th and 20 th weeks and type II was only found in 16th and 20th weeks in 3\% and 12\% of pits.

\section{DISCUSSION}

Kudo's pit pattern classification combined with autofluorescence image processing would be a useful approach that could allow an effective tissue evaluation aiming to detect early $\mathrm{NC}$ almost in real-time, bypassing staining techniques and preventing unnecessary biopsies. Qi et al. ${ }^{(34)}$ developed an algorithm for two-dimensional (2D) and 3D morphological quantification using images from high-magnification chromoendoscopy and endoscopic optical coherence tomography (OCT) but not relating those measures to Kudo's patterns. Currently, only a few approaches apply image processing based on Kudo's classification to analyse the pits morphology, using exogenous markers.

The methodology proposed quantify and characterize pits based on autofluorescence image processing. It gets the number of pits per sample and shape descriptors data, estimating its representative pit pattern and characterizing as $\mathrm{BC}$ or $\mathrm{NC}$ the state of the analysed week. The segmentation and quantification implementation took, on average, around three seconds per image, whereas the charac- terization stage depended on the number of analysed pits (Around 2.3 seconds per 15 pits). The whole image processing takes a few seconds. Takemura et al. ${ }^{(12)}$ succeeded in developing a semiautomated computerized system for recognition of regular pit patterns on high-magnification chromo-colonoscopy images by quantifying six shape descriptors, but it cannot be performed in real-time as it takes several minutes. Lastly, the conventional procedure takes around 70 hours from tissue dissection to image reconstruction and analysis as depicted in the workflow presented by Liu et al. ${ }^{(35)}$.

Perimeter outcomes are supported by published research studies such as the non-pathological pit size reported in Tan et al. ${ }^{(36)}$ as well as measurements stated for BC in Kudo's pit pattern classification ${ }^{(8)}$ characteristics from pits visualized in non-pathological mucosa.

The pits were morphologically characterized separately for each week. All pattern types were found in most of the treated groups, prevailing the I, III-L and IV or III-S order for the 4th and 8th weeks and III-L, I, IV, II and III-S for the 16th and 20th weeks. As different patterns can be found within each period of time, it is critical not to estimate a $\mathrm{BC} / \mathrm{NC}$ state using averaged parameter values. Previous reports suggest that types III-L or II could be the Kudo's pit patterns more frequently found. Alvarez ${ }^{(13)}$ detected the III-L and II patterns in $49 \%$ and $41 \%$ of 53 resected lesions by magnified colonoscopy, while the $53.9 \%$ and $38.2 \%$ of 76 lesions were observed through chromoendoscopy by Oliveira et al. ${ }^{(14)}$. By NBI, Tanaka et al. ${ }^{(24)}$ and Bastos ${ }^{(22)}$ found around $67 \%$ of type III-L in 84 and 39 analysed lesions, respectively. Finally, Su et al. ${ }^{(17)}$ stated types II and III-L in $34 \%$ and $31 \%$ of 110 polyps by chromoendoscopy.

Regarding to method drawbacks, as Takemura et al. ${ }^{(12)}$, we also excluded some unsuitable images, mainly because of the tissue deterioration or the pathology progress, decreasing the sample size. Higher sensitivity percentages would be more appropriate to analyse the progression of a pathology. Further, the segmentation stage required the modification of a parameter or steps due to the tissue variability (and therefore the image features) that makes difficult the original intention of developing a method applicable to any image, regardless of the experimental stage considered.

The preliminaries outcomes can be considered an advance in $2 \mathrm{D}$ pit characterization since the method offers an alternative to characterize normal colon pits, as well as to estimate early pathological stages of CRC, reducing examination times and bypassing staining techniques. It must be refined and improved to achieve suitable data in the most advanced stages of CRC and the experimental stage needs to be repeated to expand the sample size, increasing confidence in the evaluations.

Future challenges will involve the extension to 3D processing and characterization.

\section{Authors' contribution}

Erbes LA: methodology design, execution, statistical analysis, data analysis and writing the paper. Zeitoune AA: image acquisition. Torres HM and Casco VH: reviewing the paper. Adur J: data analysis, writing and reviewing the paper.

\section{Orcid}

Luciana Ariadna Erbes. Orcid: 0000-0003-3632-136X.

Ángel Alberto Zeitoune. Orcid: 0000-0001-7083-9440.

Humberto Maximiliano Torres. Orcid: 0000-0001-5913-161X.

Víctor Hugo Casco. Orcid: 0000-0002-3737-479X.

Javier Adur. Orcid: 0000-0003-2176-2226. 
Erbes LA, Zeitoune AA, Torres HM, Casco VH, Adur J. Caracterização morfológica da abertura de glândulas colônicas usando imagens de microscopia de autofluorescência. Arq Gastroenterol. 2019;56(2):191-6.

RESUMO - Contexto - O câncer colorretal é uma das patologias mais prevalentes. Seu prognóstico é ligado à detenção e ao tratamento precoces. Atualmente o diagnóstico é realizado por análise histológica de biópsias de pólipo, seguida de classificação morfológica. A classificação de padrões de Kudo é frequentemente utilizada para a diferenciação de lesões colorretais neoplásicas usando amostras coradas por hematoxilina-eosina. Poucos artigos relatam esta classificação com utilização de processamento por software de imagem, utilizando marcadores exógenos sobre as amostras. O processamento de imagens de autofluorescência é uma alternativa que pode permitir a caracterização do padrão das criptas de Lieberkühn, contornando técnicas de coloração. Objetivo - Analisar, quantificar e caracterizar a morfologia do padrão das criptas medindo os parâmetros morfológicos e descritores de forma, através do processamento e análise de imagens de microscopia de autofluorescência de campo de Widefield obtidas em amostras de tecido de cólon fresco a partir de um modelo murino de câncer colorretal. Métodos - Camundongos machos adultos BALB/cCmedc (n=27), variando de 20 a $30 \mathrm{~g}$, foram distribuídos aleatoriamente em quatro e cinco grupos de animais tratados e de controle. As amostras de cólon foram coletadas no dia zero e na $4^{\mathrm{a}}, 8^{\mathrm{a}}, 16^{\mathrm{a}}$ e $20^{\mathrm{a}}$ semanas após o tratamento com azoxometano. Segmentação bidimensional (2D), quantificação e caracterização morfológica do padrão das criptas por processamento de imagem aplicados utilizando programação macro de FIJI. Resultados - O tipo I é a morfologia da cripta prevalente entre $53 \%$ e $81 \%$ semanas do grupo controle. Os tipos III-L e III-S foram detectados em porcentagens reduzidas. A morfologia do tipo I entre os $33 \%$ e $56 \%$ foi constatada como a predominante para as $4^{\mathrm{a}}, 8^{\mathrm{a}}$ e $20^{\mathrm{a}}$ semanas de grupos tratados, seguidos pelo tipo III-L. Para a $16^{\mathrm{a}}$ semana, os 39\% dos padrões das criptas foram caracterizados como tipo III-L, seguidos pelo tipo I. Além disso, os tipos de padrão como IV, III-S e II também foram encontrados principalmente nessa ordem para quase todas as semanas tratadas. Conclusão - Estes resultados preliminares podem ser considerados um avanço na caracterização bidimensional da cripta como um processamento integral da imagem, comparando-se ao procedimento convencional; demora-se alguns segundos a mais para quantificar e caracterizar pontos não-patológicos, bem como para estimar estágios patológicos precoces do câncer colorretal.

DESCRITORES - Neoplasias colorretais. Pólipos do colo, diagnóstico. Focos de criptas aberrantes. Microscopia de fluorescência. Camundongos endogâmicos BALB C.

\section{REFERENCES}

1. Gualdrini UA, Iummato LE. Cáncer colorrectal en la Argentina. Organización, cobertura y calidad de las acciones de prevención y control. Informe, Ministerio de Salud, Presidencia de la Nación, Argentina 2012.

2. Li M, Ali SM, Umm-a-OmarahGilani S, Liu J, Li YQ, Zuo XL. Kudo's pit pattern classification for colorectal neoplasms: A meta-analysis. World J Gastroenterol. 2014;20:12656-469

3. Brenner H, Kloor M, Pox CP. Colorectal cancer. The Lancet 2014;383(9927):1490502.

4. Prieto SP, Lai KK, Laryea JA, Mizell JS, Muldoon TJ. Quantitative analysis of ex vivo colorectal epithelium using an automated feature extraction algorithm for microendoscopy image data. J Med Imaging. 2016;3:24502.

5. Iwatate M, Ikumoto T, Sano Y, Emura F, Fujimori T. Diagnóstico de las lesiones neoplásicas y no- neoplásicas y predicción de la invasión submucosa del cáncer colorrectal temprano durante la colonoscopia. Revista Colombiana de Gastroenterología. 2011;43-57.

6. Kato S, Fu KI, Sano Y, Fujii T, Saito Y, Matsuda T, et al. Magnifying colonoscopy as a non-biopsy technique for differential diagnosis of non-neoplastic and neoplastic lesions. World J Gastroenterol. 2006;12:1416-20.

7. Kudo S, Hirota S, Nakajima T, Hosobe S, Kusaka H, Kobayashi T, et al. Colorectal tumours and pit pattern. J Clin Pathol. 1994;47:880-5.

8. Kiesslich R, Galle PR, Neurath MF. Atlas of Endomicroscopy. Springer 2008.

9. Liedlgruber M. Pit Pattern Classification in Colonoscopy using Wavelets. Bachelor's thesis. University of Salzburg 2006.

10. Häfner M, Liedlgruber M, Uhl A, Vécsei A, Wrba F. Delaunay triangulation-based pit density estimation for the classification of polyps in high-magnification chromo-colonoscopy. Comput Methods Programs Biomed. 2012;107:565-81.

11. Saul C, Prolla JC, da Silva VD, Teixeira CR, Parada AA. Morphometric digital measurement of the luminal opening area of colonic crypts (pits) can differenciate the adenomas from other colonic lesions. Arq. Gastroenterol. 2009;46:107-10.

12. Takemura Y, Yoshida S, Tanaka S, Onji K, Oka S, Tamaki T, et al. Quantitative analysis and development of a computer-aided system for identification of regular pit patterns of colorectal lesions. Gastointest Endosc. 2010;72:1047-51.

13. Alvarez GB. Colonoscopia con magnificación de imágenes. Rev Chilena de Cirugía 2002;54:288-94.
14. Oliveira dos Santos CE, Malaman D, dos Santos Carvalho T, Lopes CV, Pereira-Lima JC. Malignancy in Large Colorectal Lesions. Arq Gastroenterol. 2014;3:235-39.

15. Häfner M, Gangl A, Wrba F, Kastinger C, Uhl A, Thonhauser K, et al. Comparison of $\mathrm{k}-\mathrm{NN}, \mathrm{SVM}$, and NN in pit pattern classification of zoom-endoscopic colon images using co-occurrence histograms. Proc. 5th Int. Symp. Image Signal Process. Anal. 2007;516-21.

16. Akarsu C, Sahbaz NA, Dural AC, Unsal MG, Kones O, Kocatas A, et al. FICE vs Narrow Band Imaging for In Vivo Histologic Diagnosis of Polyps. JSLS. 2016;20:1-8.

17. Su MY, Hsu CM, Ho YP, Chen PC, Lin CJ, Chiu CT. Comparative study of conventional colonoscopy, chromoendoscopy, and narrow-band imaging systems in differential diagnosis of neoplastic and nonneoplastic colonic polyps. Am J Gastroenterol. 2006;101:2711-6.

18. Tanaka T. Colorectal carcinogenesis: Review of human and experimental animal studies. J Carcinog. 2009;8:1-19.

19. Kim BJ, Park MI, Park SJ, Moon W, Park ET, Kim SE, et al. Differential Diagnosis of Colorectal Polyps with Narrow Band Imaging Colonoscopy without Magnification. Korean J Gastroenterol. 2014;63:276-82.

20. Thia KT, Kong CS, Ooi C. Narrow Band Imaging and Autofluorescence Imaging for the Detection and Optical Diagnosis of Colorectal Polyps. Proceedings of Singapore Healthcare 2010;19:51-6.

21. Hayashi N, Tanaka S, Kanao H, Oka S, Yoshida S, Chayama K. Relationship between narrow-band imaging magnifying observation and pit pattern diagnosis in colorectal tumors. Digestion. 2013;87:53-8.

22. Bastos N. Clasificación De Los Pólipos De La Mucosa Del Colon Y Recto: Uso Del Sistema De Imágenes De Banda Angosta. Revista de la Sociedad Venezolana de Gastroenterología. 2011;65:51-6.

23. Dolwani S, Singh R, Uedo N, Ragunath K. Management of Adenomas. In: Scholefield J, Eng C, eds. Colorectal Cancer: Diagnosis and Clinical Management. 2014;51-65.

24. Tanaka S, Oka S, Hirata M, Yoshida S, Kaneko I, Chayama K. Endoscopic Diagnosis of Colorectal Neoplasm Pit Pattern Diagnosis for Colorectal Neoplasia Using Narrow Band Imaging Magnification. Dig Endosc. 2006;18:52-6. 
25. Zhang J, McKenna SJ, Zhang J, Coats M, Carey F. Analysing the Surface Morphology of Colorectal Polyps: Differential Geometry and Pit Pattern Prediction. Morphology of colorectal polyps. 2014;1-6.

26. van den Broek FJC, Fockens P, van Eeden S, Reitsma JB, Hardwick JCH, Stokkers $\mathrm{PCF}$, et al. Endoscopic tri-modal imaging for surveillance in ulcerative colitis: randomised comparison of high-resolution endoscopy and autofluorescence imaging for neoplasia detection; and evaluation of narrow-band imaging for classification of lesions. Gut. 2008;57:1083-9.

27. DeconvolutionLab. [Internet]. Bigepfl.ch. 2019 [cited 28 February 2019]. Available from: http://bigwww.epfl.ch/deconvolution/

28. Erbes LA, Zeitoune AA, Casco VH, Adur J. Development of methods for deconvolution algorithms performance analysis using FIJI and Icy plugins. Proceedings of SPIE - 12th International Symposium on Medical Information Processing and Analysis. 2017;10160:1-12.

29. Schindelin J, Arganda-Carreras I, Frise E, Kaynig V, Longair M, Pietzsch T, et al. Fiji: an open source platform for biological image analysis. Nat Methods. 2012;9:676-82.
30. "Find Connected Regions" ImageJ PlugIn [Internet]. Longair.net. 2019 [cited 28 February 2019]. Available from: https://www.longair.net/edinburgh/imagej/ find-connected-regions/

31. Ferreira T, Rasband W. The ImageJ User Guide, 2011

32. Kay M, Wobbrock JO. Package 'ARTool', 2016;1-13.

33. RStudio [Internet]. RStudio. 2016 [cited 28 February 2019]. Available from: https://www.rstudio.com/

34. Qi X, Pan Y, Hu Z, Kang W. Automated quantification of colonic crypt morphology using integrated microscopy and optical coherence tomography. J. Biomed. Opt. 2008;13:1-11.

35. Liu CY, Dubé PE, Girish N, Reddy AT, Polk DB. Optical reconstruction of murine colorectal mucosa at cellular resolution. Am J Physiol Gastrointest Liver Physiol. 2015;308:721-35.

36. Tan CW, Hirokawa Y, Gardiner BS, Smith DW, Burgess AW. Colon cryptogenesis: asymmetric budding. PLoS One. 2013;8:1-18. 